\title{
₹USGS
}

Prepared in cooperation with the National Aeronautics and Space Administration and Brigham Young University

\section{Topographic Map of the Active Part of the Slumgullion Landslide on July 31, 2000, Hinsdale County, Colorado}

\author{
By James A. Messerich ${ }^{1}$ and Jeffrey A. Coe ${ }^{2}$ \\ ${ }^{1}$ USGS, Denver Federal Center, MS 913, Denver, CO 80225 \\ ${ }^{2}$ USGS, Denver Federal Center, MS 966, Denver, CO 80225
}

This report is preliminary and has not been reviewed for conformity with U.S. Geological Survey editorial standards or with the North American Stratigraphic Code.

Any use of trade, firm, or product names is for descriptive purposes only and does not imply endorsement by the U.S. Government.

This report may be obtained over the Internet from: http://geology.cr.usgs.gov

\section{Open-File Report 03-144}

\section{U.S. Department of the Interior \\ U.S. Geological Survey}




\section{Introduction}

The active part of the Slumgullion landslide, located in the San Juan Mountains of southwest Colorado (fig. 1), moves throughout the year (Coe and others, 2003) and has probably been moving for about the last 300 years (Varnes and Savage, 1996). Because the landslide is continuously moving, the topography of the landslide is continuously changing. The topography of the landslide was previously mapped using aerial photographs taken in 1985 (1:12,000-scale photographs, see Powers and others, 1992, for description of unpublished map) and 1990 (1:6,000-scale photographs, see Fleming and others, 1999, for map). These topographic maps, as well as digital elevation models derived from the maps (Powers and others, 1992), were used for numerous scientific studies of the landslide in the 1990s (e.g., Powers and Chairle, 1996; Smith, 1996; Baum and Fleming, 1996; Fleming and others, 1999). Ongoing studies that began in 1998 (see Coe and others, 2003) require knowledge of current topography. This paper presents a 1:1,000-scale topographic map of the landslide (sheets 1-4) that was made from aerial photographs taken on July 31, 2000. 


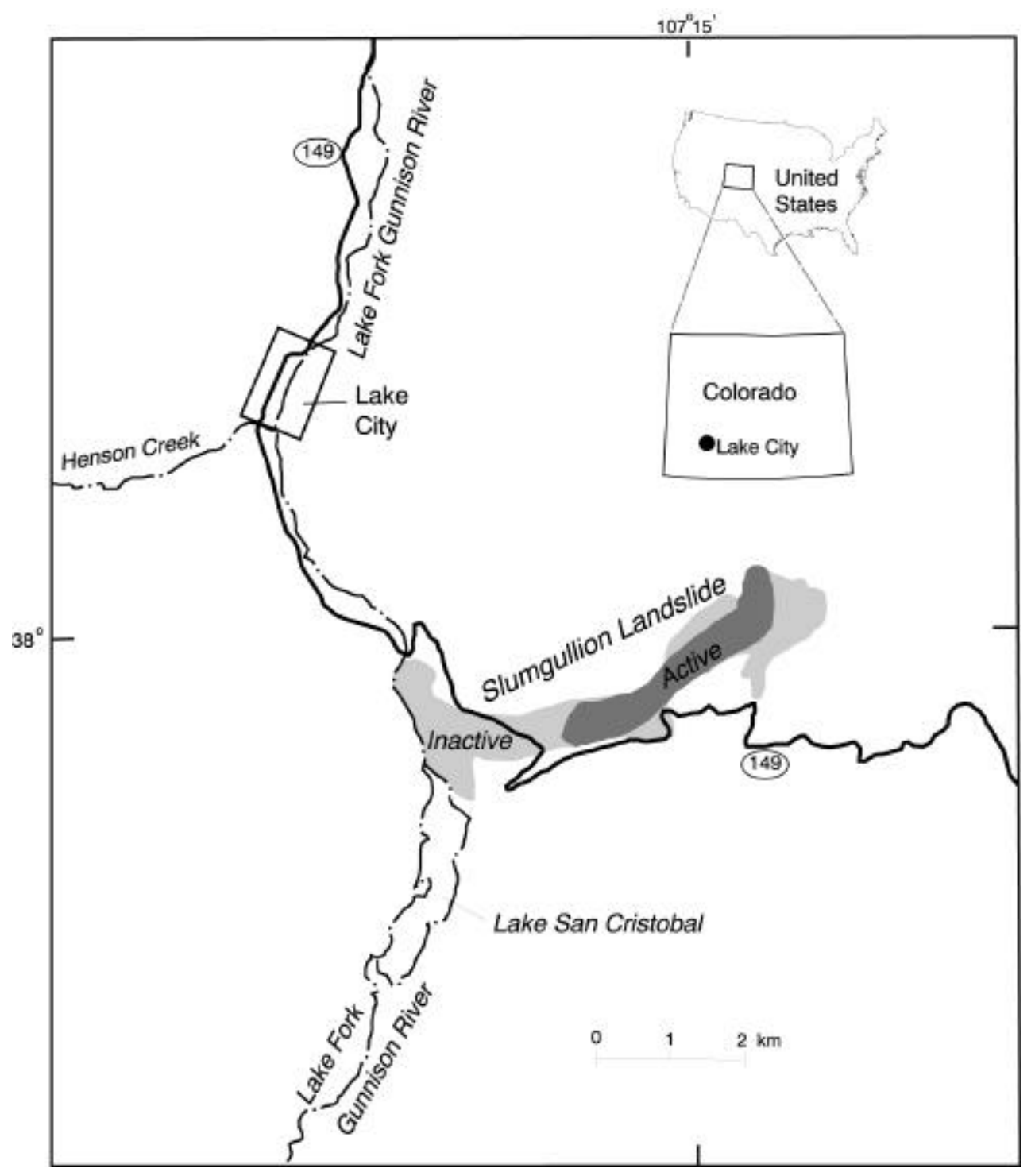

Figure 1. Map showing active and inactive parts of the Slumgullion landslide.

\section{How The Map Was Made}

The topographic map (sheets 1-4) was made using a Kern DSR-11 analytical stereo plotter (Chapius and van den Berg, 1988) and 1:6,000-scale stereo aerial photographs taken by Intrasearch, Inc. on July 31, 2000. Forty control points were used to register the photographs to the ground (fig. 2). Nineteen of the points were on nonmoving ground and served as the primary control points to register the photographs. 
Twenty-one of the points were on moving ground and served as supplemental control points (usually for elevation control only). The control points were surveyed by rapidstatic GPS survey on July 24-26, 2000. The positions of all the points were surveyed in the World Geodetic System 1984 with heights given as ellipsoid heights (see Van Sickle, 1996). Prior to using the points to register the photographs, the point positions were transformed and projected (using Prism v. 2.1 software by Ashtech, Inc.) into the Colorado State Plane (southern zone) coordinate system with heights converted to elevation above mean sea level in the North American Vertical Datum of 1988 (table 1). Therefore, coordinates shown on the map are in the Colorado State Phane coordinate system and heights are elevations above sea level. All units shown on the map are meters. The contour interval is $2 \mathrm{~m}$. Previous topographic maps of the landslide are in a local coordinate system (fig. 2) established by David Varnes in the early 1990s (Varnes and others, 1996).

\section{Acknowledgements}

We thank Bill Schulz for his critical review of this report. We also thank Jonathan Godt, Edouard Mine, John Michael, and Bill Savage for their assistance with the GPS survey of control points. We are grateful to Paco VanSistine for translating our original digital-map files into ArcInfo files. This work was funded by the NASA Solid Earth and Natural Hazards research program (NRA-MTPE-1997-10), Principal Investigators, David Arnold and David Long, Brigham Young University, and CoInvestigator, Jeff Coe, USGS. 


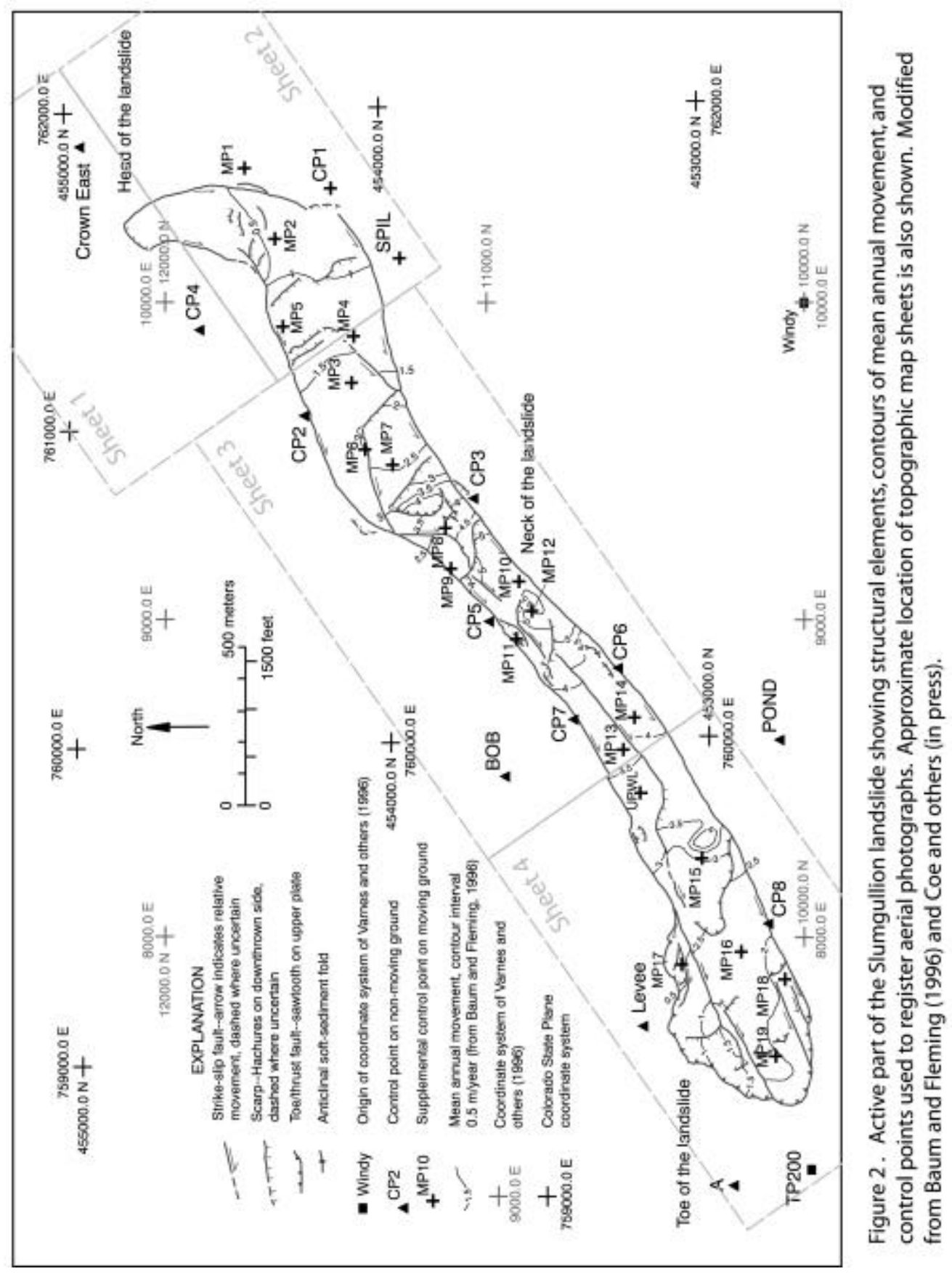


Table 1. Control points used to register aerial photography taken on July 31, 2000. Note that some of these points are not shown in figure 2 because they lie outside the area shown on the figure. A) Points located on non- moving ground. B) Points located on moving ground.

A.
\begin{tabular}{|l|l|l|l|}
\hline Point & $\begin{array}{l}\text { Easting } \\
(\mathrm{m})\end{array}$ & $\begin{array}{l}\text { Northing } \\
(\mathrm{m})\end{array}$ & $\begin{array}{l}\text { Elevation } \\
(\mathrm{m})\end{array}$ \\
\hline TP200 & 758624.74 & 452715.06 & 2945.21 \\
\hline CROWN EAST & 761899.34 & 454937.10 & 3719.98 \\
\hline LEVEE & 759092.91 & 453223.59 & 3002.67 \\
\hline CP2 & 761037.12 & 454246.82 & 3346.03 \\
\hline CP3 & 760760.79 & 453720.33 & 3295.52 \\
\hline CP4 & 761314.63 & 454567.92 & 3526.18 \\
\hline CP5 & 760376.93 & 453680.54 & 3237.13 \\
\hline CP6 & 760215.72 & 453282.78 & 3173.66 \\
\hline CP7 & 760060.76 & 453422.54 & 3165.14 \\
\hline CP8 & 759405.93 & 452829.54 & 3044.51 \\
\hline A & 758579.47 & 452953.54 & 2958.97 \\
\hline SPIL & 761510.31 & 453890.34 & 3421.55 \\
\hline SADD & 762406.23 & 453658.31 & 3502.79 \\
\hline VIEW & 762416.81 & 454314.71 & 3533.66 \\
\hline BOB & 759886.45 & 453609.55 & 3266.83 \\
\hline SWITCH & 758049.43 & 452152.90 & 3004.62 \\
\hline FERD & 756817.27 & 454056.47 & 2696.89 \\
\hline POND & 760013.78 & 452750.54 & 3085.66 \\
\hline TWIN & 757994.87 & 453420.13 & 3009.94 \\
\hline
\end{tabular}

B.

\begin{tabular}{|l|l|l|l|}
\hline MP1 & 761816.78 & 454426.35 & 3447.34 \\
\hline MP2 & 761594.24 & 454334.00 & 3426.24 \\
\hline MP3 & 761131.58 & 454100.57 & 3351.97 \\
\hline MP4 & 761281.10 & 454092.85 & 3367.54 \\
\hline MP5 & 761315.00 & 454309.04 & 3399.46 \\
\hline MP6 & 760920.39 & 454055.24 & 3334.77 \\
\hline MP7 & 760874.63 & 453976.57 & 3321.38 \\
\hline MP8 & 760662.88 & 453810.23 & 3276.77 \\
\hline MP9 & 760538.86 & 453795.26 & 3267.85 \\
\hline MP10 & 760492.95 & 453581.18 & 3233.45 \\
\hline MP11 & 760310.89 & 453597.57 & 3207.50 \\
\hline MP12 & 760396.17 & 453544.84 & 3218.65 \\
\hline MP13 & 759953.29 & 453269.19 & 3140.65 \\
\hline MP14 & 760053.71 & 453229.86 & 3154.40 \\
\hline MP15 & 759605.87 & 453032.55 & 3083.86 \\
\hline MP16 & 759309.95 & 452920.83 & 3040.19 \\
\hline MP17 & 759281.46 & 453106.43 & 3038.90 \\
\hline MP18 & 759224.68 & 452779.54 & 3026.01 \\
\hline MP19 & 758982.89 & 452818.25 & 3008.44 \\
\hline CP1 & 761747.06 & 454149.73 & 3436.03 \\
\hline UPWL & 759832.76 & 453219.50 & 3113.95 \\
\hline
\end{tabular}




\section{References}

Baum, R.L. and Fleming, R.W., 1996, Kinematic studies of the Slumgullion landslide, Hinsdale County, Colorado, in Varnes, D.J. and Savage, W.Z., eds., The Slumgullion earth flow: A large-scale natural laboratory: U.S. Geological Survey Bulletin 2130, p. 912.

Chapius, A. and van den Berg, 1988, The new Kern DSR series of first order analytical stereo plotters: International Society of Photogrammetry and Remote Sensing, 16th International Congress, Commission II, Kyoto, 8 p.

Coe, J.A., Ellis, W.L., Godt, J.W., Savage, W.Z., Savage, J.E, Michael, J.A., Kibler, J.D., Powers, P.S., Lidke, D.J., and Debray, S., 2003, Seasonal movement of the Slumgullion landslide determined from Global Positioning System surveys and field instrumentation, July 1998 - March 2002: Engineering Geology, v. 68, p. 67-101.

Fleming, R.W., Baum, R.L., and Giardino, M., 1999, Map and description of the active part of the Slumgullion landslide, Hinsdale County, Colorado: U.S. Geological Survey Miscellaneous Investigation Series Map I-2672, scale 1:1,000.

Powers, P.S., Varnes, D.J., Savage, W.Z., 1992, Digital elevation models for Slumgullion landslide, Hinsdale County, Colorado based on 1985 and 1990 aerial photography: U.S. Geological Survey Open-File Report 92-535, 5 p. 
Powers, P.S. and Chiarle, M., 1996, A digital photogrammetric method to measure horizontal surficial movements on the Slumgullion landslide, Hinsdale County, Colorado, in Varnes, D.J., and Savage, W.Z., eds., The Slumgullion earth flow: A large-scale natural laboratory: U.S. Geological Survey Bulletin 2130, p. 51-55.

Smith, W.K., 1996, Photogrammetric determination of slope movements on the Slumgullion landslide, in Varnes, D.J., and Savage, W.Z., eds., The Slumgullion earth flow: A large-scale natural laboratory: U.S. Geological Survey Bulletin 2130, p. 57-60.

Van Sickle, J., 1996, GPS for land surveyors: Chelsea, Michigan, Ann Arbor Press, 209 p.

Varnes D.J., and Savage, W.Z., 1996, Introduction, in Varnes D.J., and Savage, W.Z., eds., The Slumgullion earth flow: A large-scale natural laboratory: U.S. Geological Survey Bulletin 2130, p. 1-4.

Varnes, D.J., Smith, W.K., Savage, W.Z., and Powers, P.S., 1996, Deformation and control surveys, Slumgullion landslide, in Varnes, D.J., and Savage, W.Z., eds., The Slumgullion Earth Flow: A large-scale natural laboratory: U.S. Geological Survey Bulletin 2130, p. 43-49. 